\title{
PENERAPAN PEMBELAJARAN BERBASIS ALTERNATIVE SOLUTIONS WORKSHEET UNTUK MENINGKATKAN KEMAMPUAN BERPIKIR KREATIF MATEMATIK
}

\author{
Usman Aripin ${ }^{1}$, Ratni Purwasih ${ }^{2}$ \\ IKIP Siliwangi \\ Email: usmanaripin@gmail.com ${ }^{1)}$ \\ ratnipurwasih61@gmail.com ${ }^{2)}$
}

\begin{abstract}
This research is motivated by the low ability of mathematical creative thinking of high school students of class X IPA. To overcome these problems required one of the learning models are expected to develop creative thinking skills and mathematical disposition of students is based on Alternative Solutions Worksheet. Through this learning, students are directly involved and learn to come up with ideas in solving open ended problems, so that the students interest to be active during the learning process. It is expected that through this learning, students become motivated, resilient. The output form of this research is an open ended alternative worksheet solution which can be utilized by teachers for teaching materials. The research method used is quasi experimental with design form of Nonequivalent Control Group Design, where the research subjects are not grouped randomly. The data in this study were collected through the pretest and posttest of mathematical ability as well as the scale of the students' mathematical disposition. The results of this study are classes that use learning alternative solution worksheet better than conventional class.
\end{abstract}

Keywords: creative thinking ability, alternative solutions worksheet based learning

\section{PENDAHULUAN}

Matematika merupakan salah satu bagian yang penting dalam bidang ilmu pengetahuan. Apabila dilihat dari sudut pengklasifikasian bidang ilmu pengetahuan, matematika termasuk ke dalam ilmu-ilmu eksakta yang lebih banyak memerlukan berpikir kreatif dari pada hapalan. Siswa harus mampu menguasai konsep-konsep pokok bahasan yang terkait, sehingga siswa dapat memahami suatu pokok bahasan materi dalam matematika untuk dapat memahami dan berpikir kreatif dalam memecahkan masalah yang dihadapinya.

Selain itu, matematika juga merupakan salah satu mata pelajaran yang mesti di kuasai oleh siswa karena hampir setiap jenjang pendidikan matematika dipelajari. Matematika juga sering menjadi salah satu instrumen untuk seleksi masuk ke sebuah lembaga misalkan perguruan tinggi, penerimaan tenaga kerja, Tes akademi militer, akademi kepolisian dll. Selain itu PISA (Program for International Student Assessment) yang melakukan penilaian tingkat dunia untuk menguji kemampuan siswa-siswa yang berusia 15 tahun salah satu instrumennya adalah matematika.

Matematika sering diartikan sebagai hitung-hitungan atau menggunakan rumus-rumus untuk menyelesaikan soal. Hal ini terjadi karena sistem pembelajarannya lebih menekankan pada hafalan rumus dan mengitung untuk menyelesaikannya. Matematika juga merupakan proses berpikir. Hal ini sejalan dengan Khalid (Nasrullah \& Marsigit, 2016) mengatakan bahwa berpikir matematis merupakan metode matematis 
dalam berpikir yang digunakan untuk menyelesaikan setiap masalah dalam kehidupan sehari-hari, termasuk di sekolah. Berpikir matematis didefinisikan sebagai mengaplikasikan teknik matematis, konsep, atau proses secara implisit dan ekspilisit dalam penyelesaian masalah. Padahal matematika bukan hanya sekedar hitunghitungan dan menerapkan rumus-rumus tetapi untuk mengasah kemampuan berpikir dan bernalar siswa.

Soedjadi (Alimuddin, 2009) menyatakan bahwa salah satu fungsi matematika sekolah adalah sebagai sarana penataan nalar peserta didik. Dengan mempelajari metematika, siswa diharapkan dapat bernalar dan berpikir secara logis, analitis, kritis, dan kreatif. Inilah yang menjadikan matematika menjadi salah satu mata pelajaran yang penting untuk dipelajari di berbagai jenjang karena itu menurut Russeffendi (2010) matematika merupakan ratunya ilmu yang artinya matematika pelayan bagi beberapa disiplin ilmu lainnya.

Konsep atau rumus kalau diberikan secara langsung akan menjadi hafalan tetapi apabila sebuah pembelajaran yang didalamnya bertujuan untuk memahami atau menemukan konsep akan mengasah kemampuan berpikir kritis dan kreatif siswa. Kemampuan berpikir sangatlah diperlukan untuk mengadapi perkembangan ilmu pengetahuan, teknologi yang begitu cepat dan persaingan yang ketat. Apalagi kemampuan berpikir kreatif diharapkan dapat menciptakan inovasi-inovasi untuk kemaslahatan dirinya dan lingkungannya. Karena itulah matematika menjadi salah satu sarana untuk mengasah kemampuan berpikir kreatif siswa.

Namun kenyataan dilapangan kemampuan berpikir kreatif matematika masih rendah dilhat dari hasil PISA beberapa tahun sebelumnya hasilnya belum memuaskan. Hal ini berdasarkan studi PISA beberapa tahun sebelumnya belum menunjukan hasil yang memuaskan. Hasil studi tahun terakhir yaitu tahun 2015 dengan skor 386 dalam bidang kompetensi matematika mengalami kenaikan jika dibandingkan dengan tahun 2012 dengan skor 375. Namun, jika dibandingkan dengan rata-rata keseluruhan yaitu 490 tingkat capainya masih di bawah rata-rata (OECD, 2016).

Selian itu, hasil studi TIMSS pada tahun 2015 (Rahmawati, 2017) mengungkapkan bahwa siswa Indonesia perlu penguatan kemampuan mengintegrasikan informasi, menarik simpulan, serta menggeneralisir pengetahuan yang dimiliki ke hal-hal yang lain. Siswa Indonesia masih perlu dikembangkan lagi untuk kemampuan matematika tingkat tinggi, salah satu berpikir tingkat tinggi adalah kemampuan berpikir kreatif. Melalui pembelajaran matematika siswa diharapkan mampu mengembangkan kemampuan berfikir kreatif dan memiliki sikap ingin tahu terhadap matematika.

Selain aspek kognitif yang diukur juga oleh TIMSS pada tahun 2011 (Sumarmo, 2014) yakni sikap terhadap matematika. Berdasarkan laporan TIMSS 2011 mengenai sikap terhadap matematika terlihat bahwa siswa Indonesia yang menyukai belajar matematika masih di bawah rata-rata internasional, sedangkan siswa Indonesia yang tidak menyukai matematika menunjukkan hasil yang lebih baik, hanya sekitar 10\%. Namun, siswa yang menyukai matematika tidak dapat dipandang keseluruhan dari bagian disposisi matematis.

Untuk dapat meningkatkan kemampuan berpikir kreatif matematis siswa diperlukan sebuah teknik pembelajaran yang dapat merangsang kemampuan berpikir. Salah satu solusi dari masalah diatas yaitu dengan pembelajaran berbasis lembar kerja Alternative Solutions Worksheet (ASW). LKS berbasis ASW merupakan sebuah lembar kerja siswa yang menuntut siswa menjawab sebuah pertanyaan dengan lebih dari satu jawaban. LKS berbasis ASW dikembangkan untuk mendorong keterlibatan siswa dengan solusi alternative untuk masalah matematika selama pembelajaran (Lee, tanpa tahun).

Dalam LKS berbasis ASW soalsoal yang digunakan soal terbuka (openended). Pembelajaran menggunakan LKS ASW ini siswa terlatih untuk berpikir 
kreatif menemukan cara lain untuk membuat jawaban berbeda dari jawaban sebelumnya. Dengan pembelajaran tersebut diharapkan kemampuan berpikir kreatif siswa akan meningkat.

Selain itu, melalui LKS Alternative Solutions Worksheet juga diberi kesempatan untuk mengeksplorasi kemampuan mereka melalui soal-soal bersifat open ended, dan juga melihat hubungan antara pengetahuan yang mereka peroleh dengan kehidupan sehari-hari. Berkaitan dengan perangkat pembelajaran, Siswono (Suryadinata, 2015) mengemukakan bahwa perangkat pembelajaran yang menekankan berpikir kreatif dalam matematika tidak tersedia. Proses mengeksplorasi ide-ide untuk menjawab berbagai soal matematika yang bersifat terbuka diharapkan dapat menimbulkan rasa ingin tahu. Proses dalam melihat hubungan dengan kehidupan sehari-hari akan berakibat siswa dapat menilai bagaimana aplikasi matematika ke situasi lain dalam pengalaman sehari-hari, dan memahami peran matematika dalam kehidupan sehari-hari.

Pembelajaran berbasis lembar kerja Alternative Solutions Worksheet (ASW) diharapkan salah satu alternative untuk meningkatkan kemampuan berpikir kreatif matematis siswa. Berpikir merupakan sebuah tindakan yang tidak gegabah dan menggunakan akal rasional dalam menentukan keputusan. Menurut Clark (Azhari, 2013) berpikir adalah keadaan berpikir rasional, dapat diukur. Dapat dikembangkan dengan latihan sadar dan sengaja. Tujuan berpikir untuk menemukan pemahaman atau pengertian yang dikehendaki. Dengan berpikir akan lebih meyakinkan dalam menemukan sebuah jalan atau solusi dari permasalahan.

Evans (Putra, Irwan \& Vionanda, 2012) mengartikan kreativitas sebagai kemampuan untuk mencipta atau berkreasi, sedangakan menurut Campbell (Putra, Irwan \& Vionanda, 2012 ) kreativitas adalah kegiatan yang mendatangkan hasil yang sifatnya baru dan berguna. Semiawan (Sumarmo, 2014) mengemukakan bahwa kreativitas adalah kemampuan menyusun ide baru dan menerapkannya dalam pemecahan masalah dan kemampuan mengidentifikasi asosiasi antara dua ide yang kurang jelas. Silver dan sriraman (Sumarmo, 2014) mendefinisiskan kreatif matematik sebagai kemampuan pemecahan masalah dan berpikir matematik secara deduktif dan logik.

Indikator kemampuan berpikir kreatif dalam penelitian ini adalah menghasilkan gagasan-gahasan yang bervariasi dan berbeda dari sebelumnya, kemampuan siswa merancang solusi yang belum pernah diajarkan oleh guru dan menyelesaikan masalah secra tidak umum

Dalam penelitian ini permasalahan dibatasi pada kajian aspek kemampuan berpikir kreatif matematis melalui pembelajaran berbasis Alternative Solutions Worksheet.

\section{METODE PENELITIAN}

Penelitian yang digunakan adalah penelitian Quasi Experimental dengan bentuk desain Nonequivalent Control Group Design, dimana subyek penelitian tidak dikelompokkan secara acak. Adapun desain penelitian menurut Russeffendi (2010) yang digunakan pada penelitian ini adalah sebagai berikut :

Desain penelitian ini adalah sebagai berikut ini:
A O $\mathrm{X} O$
Kelas eksperimen
A $\mathrm{O} \quad \mathrm{O}$
Kelas kontrol

Keterangan :

$\mathrm{A}=$ acak kelas

$\mathrm{O}=$ pretes $=$ postes (tes kemampuan berpikir kreatif matematis)

$\mathrm{X}=$ Pembelajaran berbasis Alternative Solutions Worksheet (ASW)

Data dalam penelitian ini dikumpulkan melalui tes kemampuan berpikir kreatif matematis. Data kemampuan berpikir kreatif matematis siswa dikumpulkan melalui pretes dan postes. Penelitian ini diolah dengan menggunakan SPSS dengan langkahlangkah yaitu melakukan uji normalitas, melakukan uji homogenitas varians, uji Signifikan perbedaan Rata-rata, uji Gain Ternormalisasi. 
Untuk mengetahui seberapa besar peningkatan kemampuan berpikir kreatif matematik siswa sebelum dan sesudah kegiatan pembelajaran, dilakukan perhitungan gain ternormalisasi dari Hake (Sariningsih \& Purwasih, 2017), sebagai berikut:

Gain Ternomalisasi $(g)$

$=\frac{\text { Skor tes akhir }- \text { skor tes awal }}{\text { skor maksimum ideal }- \text { skor tes awal }}$

\section{HASIL PENELITIAN DAN PEMBAHASAN}

Setelah melakukan pembelajaran berbasis alternative solutions worksheet pada kelas eksperimen dan pendekatan konvensional pada kelas kontrol, selanjutnya dilakukan analisis data skor penelitian tes kemampuan berpikir kreatif. Hasil tes kemampuan berpikir kreatif terlihat pada Tabel 1 di bawah ini.

Tabel 1. Statistik Deskriptif Hasil Tes Kemampuan Berpikir Kreatif

\begin{tabular}{|c|c|c|c|c|c|c|c|}
\hline \multicolumn{2}{|c|}{} & \multicolumn{3}{c|}{ Kelas Eksperimen } & \multicolumn{3}{c|}{ Kelas Kontrol } \\
\cline { 2 - 8 } \multicolumn{2}{|c|}{ Kemampuan } & Pretes & Postes & Gain & Pretes & Postes & Gain \\
\hline \multirow{2}{*}{$\begin{array}{l}\text { Berpikir } \\
\text { Kreatif }\end{array}$} & $\bar{x}$ & 2,06 & 8,4 & 0,36 & 2,08 & 6,912 & 0,27 \\
\cline { 2 - 8 } & $\mathrm{S}$ & 1,39 & 8,44 & 0,15 & 1,38 & 3,06 & 0,15 \\
\hline
\end{tabular}

Tabel 1 di atas terlihat jelas bahwa gain kelas kontrol dan kelas eksperimen ada selisihnya yaitu sebesar 0,12 ini menunjukan bahwa terdapat perbedaan yang signifikan antara kelas eksperimen dan kelas kontrol. Data postes kemampuan berpikir kreatif matematik digunakan uji t. Uji t' dilakukan dengan menggunakan bantuan software SPSS 21. Hipotesisnya dirumuskan sebagai berikut ini:

$\mathrm{H}_{0}: \mu_{1} \leq \mu_{2}$ : Peningkatan kemampuan berpikir kreatif matematik siswa yang pembelajarannya menggunakan pembelajaran berbasis alternative solutions worksheet tidak lebih baik atau sama dengan siswa yang pembelajarannya menggunakan pendekatan konvensional.

$\mathrm{H}_{\mathrm{A}}: \mu_{1}>\mu_{2}$ : Peningkatan kemampuan berpikir kreatif matematik siswa yang pembelajarannya menggunakan pembelajaran berbasis alternative solutions worksheet lebih baik daripada siswa yang pembelajarannya menggunakan pendekatan konvensional Kriteria pengujian :

Jika Sig $\geq 0,05$ maka $\mathrm{H}_{0}$ diterima

Jika Sig < 0,05 maka $\mathrm{H}_{0}$ ditolak

Tabel 2.Hasil Uji t Data Gain

\begin{tabular}{|c|c|c|c|c|c|c|}
\hline \multicolumn{7}{|c|}{ t-test for Equality of Means } \\
\hline \multirow[t]{2}{*}{ Gain } & \multirow[t]{2}{*}{$\mathrm{T}$} & \multirow[t]{2}{*}{ Df } & \multirow{2}{*}{$\begin{array}{c}\text { Sig. } \\
(2- \\
\text { tailed) }\end{array}$} & \multirow[t]{2}{*}{$\begin{array}{c}\text { Mean } \\
\text { Difference }\end{array}$} & \multicolumn{2}{|c|}{$\begin{array}{c}95 \% \text { Confidence } \\
\text { Interval of the Difference }\end{array}$} \\
\hline & & & & & Lower & Upper \\
\hline $\begin{array}{l}\text { Equal variances } \\
\text { assumed }\end{array}$ & 2.549 & 70 & 0.013 & 0.08833 & 0.01922 & 0.15745 \\
\hline $\begin{array}{l}\text { Equal variances not } \\
\text { assumed }\end{array}$ & 2.549 & 69.9 & 0.013 & 0.08833 & 0.01922 & 0.15745 \\
\hline
\end{tabular}

Terlihat pada Tabel 2 didapat Sig sebesar 0,013. Menurut Uyanto (2009: 145) karena kita akan menguji 1 arah (1-tailed) maka signifikasi untuk 2tailed harus di bagi dua. Nilai signifikansinya adalah $\frac{0,013}{2}=0,0065$. Karena sig $<0,05$ dengan kata lain $\mathrm{H}_{0}$ ditolak artinya Peningkatan kemampuan berpikir kreatif matematik siswa yang 
pembelajarannya menggunakan pembelajaran berbasis alternative solutions worksheet lebih baik daripada siswa yang pembelajarannya menggunakan pendekatan konvensional pada taraf signifikansi $5 \%$.

Tujuan dari penelian ini adalah untuk mengetahui peningkatan berpikir kreatif matematis siswa SMA yang menggunakan pembelajaran alternative solution worksheet dan disposisi terhadap pembelajaran matematika.
Mengacu pada pernyataan tersebut, kegiatan pembelajaran yang di berikan pada kelas kontrol dengan pembelajaran ekspositori dan pada kelas eksperimen dengan pembelajaran alternative solution worksheet sangat berbeda sekali, baik itu pada tingkat keaktifan siswa, cara belajar siswa atau pun antusias semangat siswa terhadap pelajaran matematika, hal tersebut terlihat pada gambar berikut:

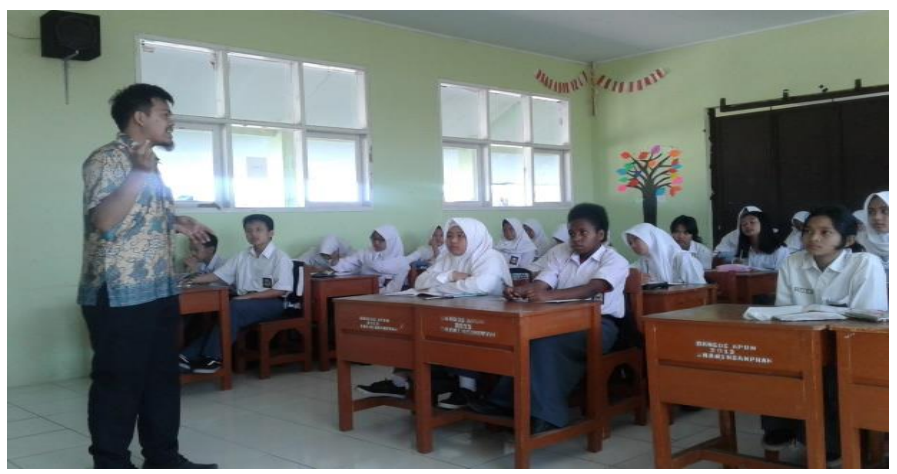

Gambar 1. Suasana Belajar Kelas Konvensional

Pada Gambar 1 karakteristik pembelajaran konvensional membuat suasana kelas cendrung bosan, siswa selalu mengerjakan prosedur dan langkah pengerjaan sesuai contohcontoh yang diberikan oleh guru, dan tidak adanya proses diskusi sehingga siswa yang belum paham mengenai apa yang sedang dipelajari takut bertanya dan bahkan cendrung membiarkan ketidak pahamannya dikarnakan tidak adanya kesempatan untuk bertanya maupun berdiskusi. Sejalan dengan Hiebert, James, Carpenter, Thomas (1992), bukti menunjukan jika siswa belajar dengan mengingat dan latihan prosedural, mereka akan kesulitan dalam memperoleh tes konsep konsep mematika secara mendalam.

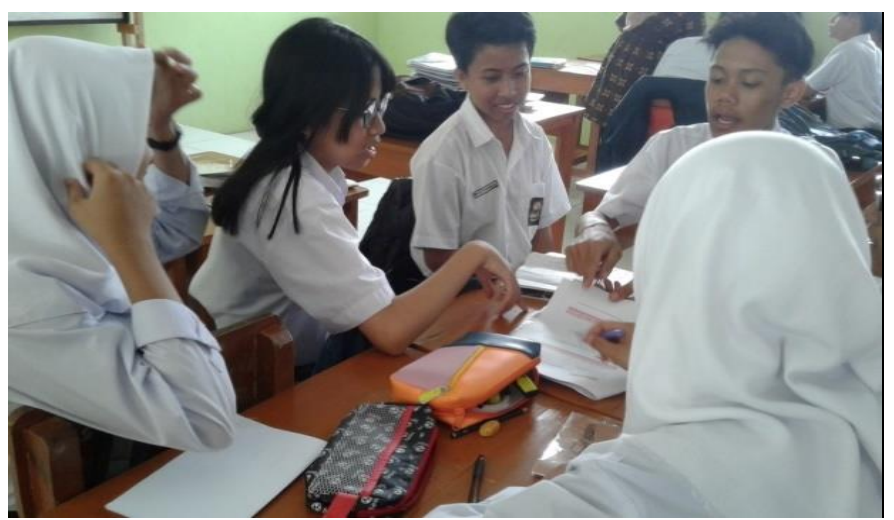

Gambar 2. Aktifitas Siswa yang Memperoleh Pembelajaarn ASW 
Hasil analisis penelitian menunjukkan bahwa pencapaian peningakan kemampuan berpikir kreatif matematik dan disposisi matematis siswa yang memperoleh pembelajaran lebih baik daripada yang memperoleh pembelajaran biasa. Berdasarkan pengamatan di lapangan kemampuan berpikir kreatif matematik dan disposisi matematis siswa kelas yang menggunakan pembelajaran alternative solution waorksheet lebih baik dikarenakan siswa terbiasa mencari tahu sendiri juga menyelesaikan masalah hasil pemikiran sendiri. Selain itu selama pengumpulan informasi terjadi kegiatan berpikir yang kemudian akan menimbulkan pemahaman yang mendalam dalam belajar dan akan mendorong terjadinya pemusatan perhatian terhadap topik sehingga membuat siswa menggali lebih banyak informasi yang membuat hasil belajar lebih bermutu (Umbara, 2016:144).

Berbeda dengan kelas yang menggunakan pembelajaran biasa karena pada kelas kontrol siswa terbiasa menerima penjelasan dari guru sehingga siswa besar kemungkinan mengalami kesulitan jika tidak mendapat bantuan dari guru. Untuk keaktifan berdiskusi kelompok siswa kelas eksperimen sebagian besar kelompok berdiskusi dengan aktif, sedangkan pada kelas kontrol hanya sebagian kecil kelompok yang berdiskusi dengan aktif dan interaktif.

Kualifikasi rerata pretes kemampuan berpikir kreatif matematik kedua kelompok sampel berada pada katagori kurang, karena persentase rerata dari skor ideal masing-masing kelompok sampel kurang dari $50 \%$. Setelah diberikan perlakuan pembelajaran yang berbeda kepada masing-masing kelompok sampel, hasil postes menunjukan perbedaan yang signifikan antara kedua kelompok sampel. Pencapaian kemampuan berpikir kreatif matematik siswa yang memperoleh pembelajaran alternative solutions worksheet berada pada katagori baik, sedangkan kelompok sampel pembelajaran konvensional berada pada katagori rendah. Berdasarkan hasil tersebut menunjukan bahwa pencapaian kemampuan berpikir kreatif siswa yang mendapatkan pembelajaran alternative solutions worksheet lebih baik dari pada siswa yang mendapatkan pembelajaran dengan pembelajaran konvensional. Russefendi (2010) mengatakan bahwa eqivalensi subjek dalam kelompokkelompok yang berbeda perlu ada, agar bila ada hasil yang berbeda yang diperoleh kelompok, itu bukan disebabkan Karena tidak eqivalennya kelompok- kelompok itu, tetapi karena adanya perlakuan.

Berdasarkan gain ternomalisasi Meltzer (2002), kualifikasi rerata postes kemampuan berpikir kreatif pada kelas eksperimen berada pada katagori sedang $(0,36)$, sedangkan rerata postes kemampuan berpikir kreatif pada kelas kontrol berada pada katagori rendah $(0,27)$. Sehingga peningkatan kemampuan berpikir kreatif matematik siswa yang pembelajarannya alternative solutions worksheet lebih baik dari pada siswa yang pembelajarannya menggunakan konvensional. Pembelajaran alternative solutions worksheet yang didukung oleh worksheet yang open ended dapat mempermudah, dan menarik perhatian siswa dalam menyelesaikan permasalahan yang diberikan. Karena Lembar kerja atau worksheet merupakan kumpulan materi pelajaran dan soal-soal latihan untuk membimbing siswa lebih sistematis dan terarah proses belajarnya. Menurut Choo, Serene S. Y. et all (Indriyati, 2015, p.31) worksheet adalah alat 
instruksional yang terdiri dari serangkaian pertanyaan dan informasi yang didesain sebagai petunjuk siswa agar memahami ide-ide yang kompleks karena mereka bekerja melalui secara sistematis

Dalam menyelesaikan soal kemampuan berpikir kreatif pada siswa yang menggunakan pembelajaran alternative solution worksheet (ASW) masih memiliki kesulitan yaitu dalam indikator Kemampuan siswa merancang solusi yang belum pernah diajarkan oleh guru dimana siswa harus memberikan jawaban lebih dari satu dan sebelumnya belum pernah guru ajarkan. Kebanyak siswa belum mampu menyelesaikan dan beberapa yang bias mengerjakan tetapi memberikan hanya satu jawaban dalam soal berindikator Kemampuan siswa merancang solusi yang belum pernah diajarkan oleh guru. Berbeda dengan kelas yang menggunakan pembelajaran biasa, sebagian besar siswa masih kesulitan menyelesaikan soal berindikator Menghasilkan gagasangahasan yang bervariasi dan berbeda dari sebelumnya. Siswa di kelas kontrol terbiasa menyelesaikan soal sesuai dengan cara yang telah guru ajarkan. Ikhsanudin (2014) mengatakan bahwa mereka cenderung senang dengan cara yang singkat dibandingkan dengan cara yang panjang seperti langkah penyelesaian masalah yang disediakan pada lembar jawaban. Pada indikator menghasilkan gagasan-gahasan yang bervariasi dan berbeda dari sebelumnya siswa kelas kontrol masih kesulitan untuk menambahkan atau memprinci dan memperkarya juga mengembangkan suatu gagasan. Sedangkan pada indikator Kemampuan siswa merancang solusi yang belum pernah diajarkan oleh guru siswa kelas kontrol masih kesulitan untuk membuat kombinasi-kombinasi dari bagianbagian atau unsur-unsur. Seperti terlihat pada Gambar 1 di bawah ini.

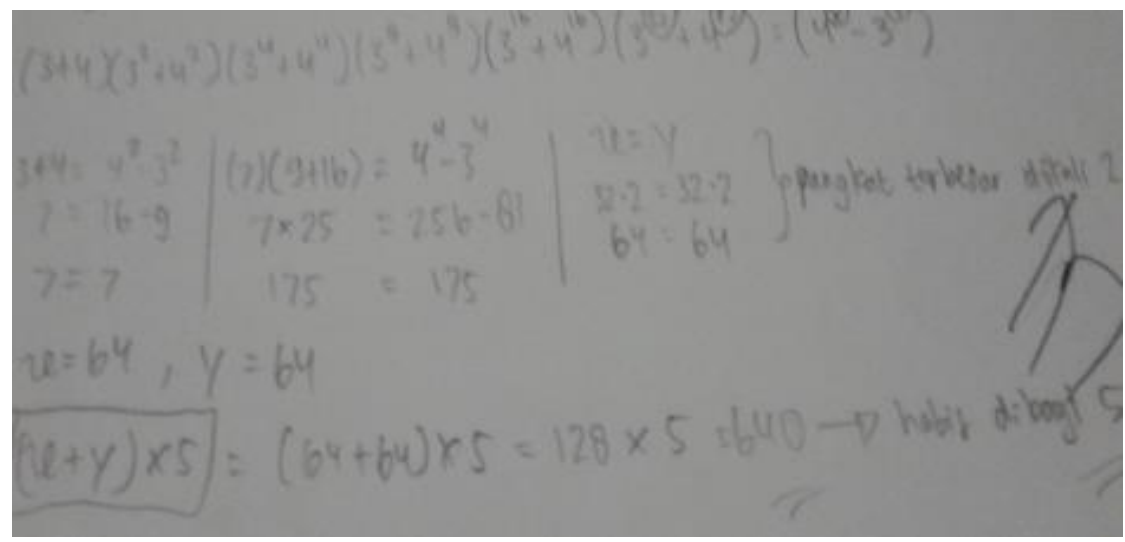

Gambar 3. Jawaban Siswa

Gambar di atas menunjukan bahwa siswa mmapu memberikan jawaban terhadap soal yang menuntut mereka untuk mendesain penyelesaian sedemikian rupa sehingga permasalahan terselesaikan secara benar.

Secara umum sebagian besar siswa pada kelas yang menggunakan pendekatan alternative solution worksheet benar dalam menjawab soal kemampuan berpikir kreatif matematik. Berbeda dengan kelas yang menggunakan pembelajaran biasa yang sebagian besar siswanya masih menjawab salah soal kemampuan berpikir kreatif matematik. 


\section{KESIMPULAN DAN SARAN}

Berdasarkan hasil penelitian dan pembahasan pada bab $\mathrm{V}$, dapat disimpulkan beberapa hal yang berkaitan dengan pembelajaran matematika dengan menggunakan pembelajaran Alternative Solution Worksheet (ASW) yaitu: peningkatan kemampuan berpikir kreatif matematik siswa yang menggunakan pembelajaran Alternative Solution Worksheet lebih baik daripada siswa yang menggunakan pembelajaran konvensional; pembelajaran yang menggunakan pendekatan Alternative Solution Worksheet membuat siswa lebih aktif, lebih berpikir kreatif, mandiri, dan lebih termotivasi

Berdasarkan temuan dalam penelitian ini, maka beberapa saran dari penelitian ini yaitu: untuk lebih meningkatkan kemampuan berpikir kreatif matematik siswa melalui pembelajaran dengan pendekatan Alternative Solution Worksheet hendaknya diberikan waktu yang lebih pada fase mengidentifikasi masalah, mencari informasi, dan menggunakan informasi hanya terbatas pada kemampuan berpikir kreatif matematik matematis siswa, oleh karena itu disarankan kepada peneliti lain dapat melanjutkan penelitian pada kemampuan matematik dan skala sikap yang lain dengan menggunakan pendekatan Alternative Solution Worksheet; fokus penelitian ini hanya pada aspek berpikir kreatif dan disposisi matematik siswa SMA, oleh karena itu peneliti lain dapat mengkaji lebih lanjut tentang korelasi antara kemampuan berpikir kreatif matematik matematik siswa SMA.

\section{DAFTAR PUSTAKA}

Alimuddin (2009). Menumbuh Kembangkan Kemampuan Berpikir Kreatif Siswa Melalui Tugas- Tugas Pemecahan Masalah. Disajikan pada Prosiding Seminar Nasional Penelitian , Pendidikan dan Penerapan MIPA 16 Mei 2009, Yogyakarta : UNY.

Azhari (2013). Meningkatkan Kemampuan Berpikir Kreatif Matematik Siswa melalui Pendekatan Konstruktivisme di Kelas VII SMP Negeri 2 Banyuasin III. Jurnal Pendidikan Matematik, 7 (2), 1-12.

Hiebert, James, Carpenter, Thomas, P. (1992). Learning And Teaching Understanding . In Grouws. Handbook "of Reseacrh on Mathematics Teaching and Learning, 65-67". New York: Mac-Millan.

Indriyati.( 2015 ). Penerapan metode worksheet plus pada proses pembelajaran materi menjaga kelangsungan hidup. Didaktikum: Jurnal Penelitian Tindakan Kelas, 16(3), 31-36.

Ikhsanudin. (2014). Pengaruh Penggunaan Pembelajaran Kooperatif Tipe Stad Berbantuan Wingeom Terhadap Kemampuan Pemecahan Masalah Geometri Siswa Sma. Jurnal Aksioma, 3(1), 40-49.

Nasrullah, A., \& Marsigit, M. (2016). Keefektifan Problem Posing dan Problem Solving Ditinjau dari Ketercapaian Kompetensi, Metode, dan Sikap Matematis. Jurnal Phytaghoras, 11(2), 123135.

Meltzer. (2002). The Relationship Between Mathematics Prerartion 
and Conceptual Learning Gains in physics : a Posible "Hiden Variable" in Diagnostics Pre Test Skores. Vol. 7. Page. 1259-1268. Physics Education Research Grup [Online].

http://www.physics.iastate.edu./pe r/arthicles/index/html.

Lee, Shin-Yi. Tanpa tahun. The Effect of Alternative Solutionss on Problem Solving Performance. Journal of Taipei Municipal University of Education. Tidak ada nomor. pp: 1-17

OECD (2012). Programe For International Student Assessment (PISA) Results From PISA 2012. [online]. Tersedia: http://www.oecd.org/unitedstates/ PISA-2012-results-US.pdf

Putra, T. T., \& Irwan. Vionanda, D. (2012). Meningkatkan

Kemampuan berpikir Kreatif Siswa dengan Pembelajaran Berbasis masalah. Jurnal Pendidikan Matematka Universitas Padang, 1(1), 22-26.

Rahmawati.(2017). Seminar Hasil TIMMS2015. PuspendikKemdikbud.

Russeffendi, E.T (2010). Dasar-dasar Penelitian Pendidikan dan Bidang Non-Eksakta Lainnya. Bandung: Tarsito.
Sariningsih, R., \& Purwasih, R. (2017). Pembelajaran Problem Based Learning Untuk Meningkatkan Kemampuan Pemecahan Masalah Matematis Dan Self Efficacy Mahasiswa Calon Guru. Jurnal JNPM (Jurnal Nasional Pendidikan Matematika), 1(1), 163-177.

Sumarmo, U.(2014). Pendidikan Karakter serta Pengembangan Berpikir dan disposisi Matematik dalam Pembelajaran Matematika. Disajikan pada Seminar Pendidikan Matematika, 25 Februari 2012. NTT.

Sumarmo, U. (2014). Berpikir dan Disposisi Matematika serta Pembelajarannya. Bandung : Jurusan Pendidikan Matematika FPMIPA-UPI.

Suryadinata, N. (2015). Pengembangan Perangkat Pembelajaran Strategi Quick On The Draw Dengan Masalah Open Ended Untuk Meningkatkan Kemampuan Berpikir Kreatif Materi Prisma Dan Limas. Jurnal Aksioma, 4(1), 9-21.

Umbara, U. (2016). Implementasi Pendekatan Resource Based Learning terhadap Peningkatan Kemampuan Pemecahan Masalah Matematis Siswa SMP. Jurnal Matematika Ilmiah STKIP Muhammadiyah Kuningan, 2(1), 133-145.

Uyanto, S.S. (2009). Pedoman Analisis Data dengan SPSS. Graha Ilmu. Yogyakarta 